\title{
Analysis of the Variability of the Composition of Sewage Sludge Before and After Drying Treatment - SEM Studies
}

\author{
Justyna Kiper ${ }^{1 *}$, Anna Głowacka', Teresa Rucińska² \\ 1 Department of Sanitary Engineering, West Pomeranian University of Technology in Szczecin, al. Piastów 50, \\ 70-311 Szczecin, Poland \\ 2 Department of Building Physics and Building Materials, West Pomeranian University of Technology in \\ Szczecin, al. Piastów 50, 70-311 Szczecin, Poland \\ * Corresponding author's e-mail: justynakiper@gmail.com
}

\begin{abstract}
The aim of the study was to determine the physical and chemical properties of the sewage sludge from "Pomorzany" and "Zdroje" municipal wastewater treatment plants located in Szczecin, Poland. The paper presents the outcomes of SEM observation of dried and stabilized sewage sludge. The research on the obtained materials was conducted using reference methods; the images from a scanning electron microscope were used. The amount of sewage sludge produced with the methods of its management was presented. The technology of sludge management is based on its dehydration up to dry weight content of roughly $20 \%$ and then drying in contact dryers up to $90-92 \%$ dry weight, separately in both plants. Dried sewage sludge is subsequently burned in mechanical grid boilers at "Pomorzany" WWTP. The analyzed materials were characterized by the $\mathrm{pH}$ of 7.90-8.42, dry mass and average organic matter content were $18.949 \%$ and $68.903 \%$, respectively. The elements identified in the largest amount on the surface of analyzed materials included calcium, iron, phosphorus, sulphur and silicon. The amount of phosphorus ranging from 1.82 to $3.44 \%$ indicates the possibility of using sewage sludge as organic fertilizer product or an alternative source of phosphorus.
\end{abstract}

Keywords: sewage sludge, sewage sludge management, SEM observation

\section{INTRODUCTION}

Improving the municipal sewage sludge management is one of the most important environmental goals in the European Union. Since 1st January 2016, storing the municipal sewage sludge in municipal landfill is forbidden by the Polish law. It obliges searching for new solutions or improving the currently used methods of management. Most importantly, it encourages taking ecological, economical and technical aspects under consideration.

"The National Program of the Waste Management 2022" is an ongoing management plan, which constitutes the main practice followed by the members of the European Union. One of the points of the Program is focused on the increasing amount of wastage [including sewage sludges] subjected to thermal transformation.
In 2016, the municipal wastewater treatment plants in Poland generated $568329 \mathrm{Mg}$ d.m. of sewage sludge. The percentage of their thermal transformation amounted to $18 \%$, improved from $11 \%$ reached in 2012 [Eurostat]. The increase of the degree in a wastewater treatment also cause increases in the total amount of sewage sludge. "National Program of the Waste Management 2022 " forecasts the annual increase of the sludge amount by $2-3 \%$ in recalculation into a dry matter [Resolution No. 88 of the Council of Ministers of 1 July 2016].

Thermal sewage sludge utilization is achieved through a variety of processes. Sewage sludge which stabilizes during aerobic or anaerobic stabilization processes is dehydrated to about $18-20 \%$ of a dry matter. Then the sludge is subjected to drying, where the dry mass reaches more than $90 \%$. 
Final sludge decomposition takes place via combustion in grate or fluidal furnance [Cornel 2011]. Presently in Poland, there are 11 municipal sewage sludge combustion plants [with grate or fluidized bed furnaces], 17 thermal and 12 solar dryers [The Ministry of the Environment 2018, Henclik et al. 2014, Niesler and Nadziakiewicz 2013].

Depending on the chemical composition of wastewater, as well as the technical solutions employed in its treatment, the sludge with different content of micro- and macroelements, including heavy metals, is obtained. Additionally, the physical characteristics of sewage sludge are linked with the technology used [machines and installations] and the method of conducting the removal process. The presence of pathogenic bacteria, viruses and other pathogenic organisms in the sewage sludge constitutes a health risk [Schröder et al. 2007, Lu et al.2009, Zorpas 2011, Ju et al. 2016].

The aim of the study was to characterize the physical and chemical properties of the municipal sewage sludge from "Pomorzany" and "Zdroje" wastewater treatment plant in Szczecin. The SEM observation of the samples of dried and dewatered sewage sludge was conducted. The possibility of employing methods for utilizing the sewage sludge was determined based on the results of this study.

\section{MATERIALS AND METHODS}

The analyzed materials were obtained from two municipal wastewater treatment plants in Szczecin (Poland). The material was collected in two repetitions in the first quarter of 2019. The studies included determination of dry matter content, $\mathrm{pH}$, organic and mineral matter in stabilized, dewatered sewage sludge. The analysis of the physicochemical properties was performed using reference methods, in accordance with the applicable standards: BS EN 12880: 2004, PN-EN 12879:2004, PN-EN 12176: 2004.

Scanning electron microscope Hitachi TM 3000 equipped with EDS unit was used in order to observe the elemental concentration spectrum and determine the elemental composition of the analyzed dried and dewatered sewage. The presented analysis results are the average of 2 replicates. The standard deviation and the coefficient of variation were calculated.

\section{Sludge management in the "Pomorzany" and "Zdroje" wastewater treatment plants}

The "Zdroje" wastewater treatment plant treats the wastewater in the right bank - one of four districts of the city. The wastewater from other districts is directed to the "Pomorzany" wastewater treatment plant. Municipal sewage and rainwater in right bank are mainly collected into separate sanitary sewer systems and storm drain. The wastewater flowing into the "Pomorzany" WWTP may include stormwater or an urban runoff.

The wastewater influent to the "Zdroje" WWTP is characterized by a large load of pollution. The average daily inflow of sewage is about $15000 \mathrm{~m}^{3}$. The capacity of the "Pomorzany" plant is $66000 \mathrm{~m}^{3} / \mathrm{d}$. The designed PE was 177000 and $417000 \mathrm{PE}$, respectively.

The main wastes generated in wastewater treatment plants include screenings, sand (preliminary treatment), initial (primary) sludge and excess sludge. The waste from bar screens and grit chambers are subjected to rinsing to reduce the organic parts content. The content of water is reduced by compression or separation. The degritted primary and excess sludge are pumped to the plant sludge handling facilities for further processing: thickening, digesting and dewatering. Compaction of sludge is carried out in both plants alike. Receiving and transporting of thickened initial and excess sludge occurs periodically. The initial sludge is periodically received from primary settling tanks. Gravitationally concentrated up to about $5 \%$ of dry weight, the sludge from the bottom of gravity thickening tanks is received and transported to the mixed sludge tank.

The biological structure of excess sludge received from the second settling tank, means that most of the water contained in it is the water bound in the cells. It requires using polyelectrolytes for conducting the conditioning processes. The excessive sludge concentrated in mechanical compactors contains about 5-6\% of dry weight.

After concentration, the mixed sludge is discharged to the digestion tanks, where it is mixed and heated up to $37-41^{\circ} \mathrm{C}$. The biogas, produced during mesophilic fermentation is stored in the double-shell tanks. After desulfurization, the biogas is used as a fuel for the electrical and thermal energy production. Discharged sludge cake can reach the dry solids contents of $18-30 \%$, depending on the dewatering technology and 
polyelectrolyte applied. Four conveyor presses and two centrifuges are used in "Pomorzany" and "Zdroje" wastewater treatment plants.

The technology of thermal disposal of sewage sludge was chosen by the Department of Water Supply and Sewage Ltd. in Szczecin. The sewage sludge dehydrated up to a dry weight content of roughly $20 \%$ dries in contact dryers up to $90-92 \%$ dry weight, separately in both plants. The dried material from "Zdroje" WWTP is transferred and burned in two mechanical grid boilers with power of $2460 \mathrm{~kW}$, in "Pomorzany" WWTP.

The general flow diagram of sludge treatment is shown in Figure 1.

\section{RESULTS AND DISCUSSION}

In 2018, 19528.27 Mg of sewage sludge was transferred for a desiccation in the "Pomorzany" WWTP, whereas in "Zdroje" it was $2853.23 \mathrm{Mg}$ (table 1). As a result of incinerating $4836.74 \mathrm{Mg}$ of dried sewage sludge, $1425.58 \mathrm{Mg}$ of ash and slag were produced. According to [Kelessidis and Stasinakis 2012], Poland was the greatest sludge producer in EU-12 countries. The mean specific sludge production expressed as $\mathrm{kg}$ DS per p.e. and year, in 2005 was 12,73 , whereas in 2015 it reached the value of $14.78 \mathrm{~kg}$ DS per p.e. [Eurostat 2019]. The selected properties characteristic of the slag formed were included in the research conducted in 2016 by Głowacka et al. [Głowacka et al. 2017].

The physical properties of the municipal sewage sludge are presented in Table 2. The average dry mass of the sludge obtained from "Pomorzany" WWTP was in range of $18.570 \pm 0.423 \%$. The dehydrated sludge from "Zdroje" WWTP has reached the content of dry mass from $18.518 \%$ to $20.286 \%$. The organic matter content as well as $\mathrm{pH}$ of sewage sludge may vary considerably [Singh and Agrawal 2008]. The $\mathrm{pH}$ value was a)

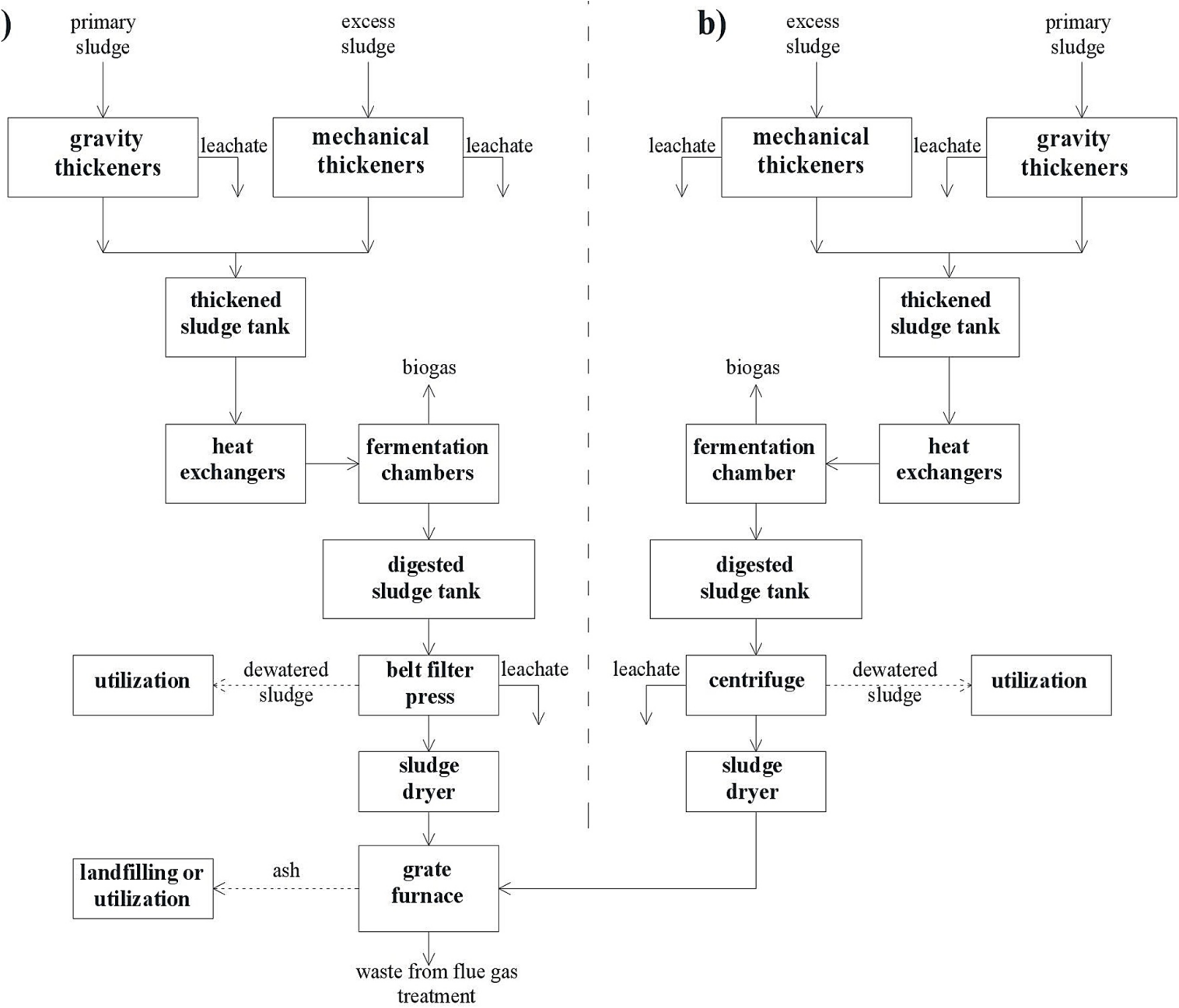

Figure 1. Flow diagram of sewage sludge management at Wastewater Treatment Plant a] "Pomorzany", b] "Zdroje" 
Table 1. Mass of dehydrated, dried and incinerated sewage sludge in wastewater treatment plants in Szczecin in 2018 (in Mg)

\begin{tabular}{|c|c|c|c|c|c|c|c|}
\hline \multirow[t]{2}{*}{ Month } & \multicolumn{2}{|c|}{$\begin{array}{c}\text { Dehydrated sewage sludge } \\
(19 \% \text { d.m. })\end{array}$} & \multicolumn{2}{|c|}{$\begin{array}{l}\text { Sewage sludge subjected to } \\
\text { desiccation (19\% d.m.) }\end{array}$} & \multicolumn{2}{|c|}{$\begin{array}{c}\text { Dried sewage sludge of } \\
\text { average content ( } 92 \pm 2 \% \text { d.m.) }\end{array}$} & \multirow{2}{*}{$\begin{array}{c}\text { Sewage } \\
\text { sludge } \\
\text { ash (ssa) }\end{array}$} \\
\hline & Zdroje & Pomorzany & Zdroje & Pomorzany & Zdroje & Pomorzany & \\
\hline January & 434.25 & 2166.8 & 287.57 & 1834.9 & 60.54 & 365.00 & 130.60 \\
\hline February & 389.45 & 1639.5 & 187.82 & 1244.0 & 39.54 & 266.57 & 89.140 \\
\hline March & 101.01 & 1978.0 & 233.70 & 1925.0 & 49.20 & 397.55 & 141.80 \\
\hline April & 383.10 & 1769.2 & 242.73 & 1177.7 & 51.10 & 239.22 & 94.760 \\
\hline May & 463.11 & 1638.7 & 240.92 & 1490.0 & 50.72 & 322.84 & 100.86 \\
\hline June & 432.02 & 1930.0 & 261.16 & 1684.6 & 54.98 & 367.39 & 138.26 \\
\hline July & 524.56 & 1708.4 & 379.81 & 1526.6 & 79.96 & 351.75 & 126.42 \\
\hline August & 377.86 & 1677.4 & 320.53 & 1653.9 & 67.48 & 409.04 & 137.38 \\
\hline September & 426.36 & 1646.7 & 43.040 & 1439.0 & 9.060 & 351.75 & 97.420 \\
\hline October & 441.87 & 1982.4 & 265.53 & 1982.4 & 55.90 & 412.99 & 135.04 \\
\hline November & 371.46 & 1842.0 & 341.91 & 1842.0 & 71.98 & 391.92 & 130.82 \\
\hline December & 375.10 & 1728.2 & 48.550 & 1728.2 & 10.22 & 360.04 & 103.08 \\
\hline sum & 4720.15 & 21707.30 & 2853.3 & 19528.3 & 600.68 & 4236.06 & 1425.6 \\
\hline average & 393.35 & 1808.94 & 237.77 & 1627.36 & 50.06 & 353.01 & 118.80 \\
\hline $\max$ & 524.56 & 2166.80 & 379.81 & 1982.40 & 79.96 & 412.99 & 141.80 \\
\hline $\min$ & 101.01 & 1638.70 & 43.04 & 1177.70 & 9.06 & 239.22 & 89.14 \\
\hline
\end{tabular}

Table 2. Characteristic of dehydrated sludge [average \pm standard deviation]

\begin{tabular}{|c|c|c|c|c|c|}
\hline Sample & $\begin{array}{c}\text { Dry mass } \\
\text { [\% d.m.] }\end{array}$ & $\begin{array}{c}\text { Humidity } \\
\text { [\% d.m.] }\end{array}$ & $\begin{array}{c}\text { Organic matter } \\
\text { [\% d.m.] }\end{array}$ & $\begin{array}{c}\text { Mineral substance } \\
\text { [\% d.m.] }\end{array}$ & $\mathrm{pH}$ \\
\hline P1' & $18.965 \pm 0.025$ & $81.035 \pm 0.025$ & $69.12 \pm 0.10$ & $30.88 \pm 0.10$ & 7.90 \\
\hline P2' & $18.179 \pm 0.059$ & $81.824 \pm 0.059$ & $68.56 \pm 0.12$ & $31.44 \pm 0.12$ & 8.26 \\
\hline Z1' & $18.832 \pm 0.283$ & $81.168 \pm 0.283$ & $69.43 \pm 0.07$ & $30.57 \pm 0.07$ & 8.05 \\
\hline Z2' & $19.820 \pm 0.578$ & $80.180 \pm 0.578$ & $68.50 \pm 0.06$ & $31.50 \pm 0.06$ & 8.42 \\
\hline mean & 18.949 & 81.052 & 68.903 & 31.098 & - \\
\hline SD & 0.6747 & 0.6758 & 0.4490 & 0.4490 & - \\
\hline CV & 0.0356 & 0.0083 & 0.0065 & 0.0144 & - \\
\hline
\end{tabular}

7.9-8.26 and 8.05-8.42, respectively. An increase in the alkalinity of the samples taken in the second term (P2, Z2) was noted. The content of organic matter and mineral substance in the various samples did not vary significantly. The average content of organic matter in the collected materials was $68.903 \pm 0.675 \%$. Higher organic matter in sewage sludge enhances the activities of soil enzymes, as well as the soil microbial activity [Singh and Agrawal 2008].

A microscopic evaluation was conducted with the use of electron microscope. The samples of dehydrated sewage sludge were previously dried on a moisture analyzer. Figure 2 and 3 show the structure of both sewage sludge samples after dehydration and desiccation. The structure of sewage sludges after thermal treatment was porous and irregular. According to Głowacka et al., the porous structure of slag results in low volumetric density and provides an advantage of convenient thermal insulation; however, it contributes to an increased water absorption and lower level of mechanical strength [Głowacka et al. 2017]. As in the reports of other researchers [Rio et al. 2005], the structure of the dehydrated sludges is mainly macroporous. Singh and Agrawal [Singh and Agrawal 2008], conducted studies which indicate that sludge improves the physical properties of the soil such as porosity, bulk density, water retention and aggregate stability.

Hitachi TM 3000 Scanning electron microscope equipped with EDS unit was used in order to determine the elemental composition of the analyzed slag - see Figure 4.

The heavy metals occurring in sewage sludge include iron, zinc, copper, nickel, chromium, as well as the elements considered toxic such as lead, cadmium, mercury [Singh and Agrawal 2008]. Toxic elements are highly harmful to humans, animals, growth and development of plants 


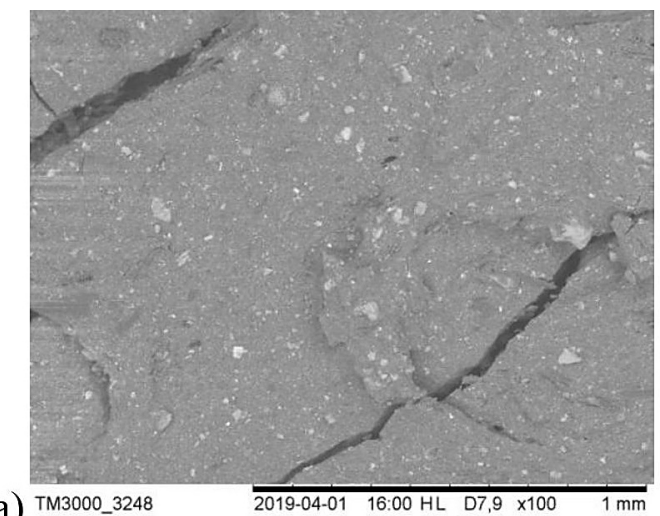

a)

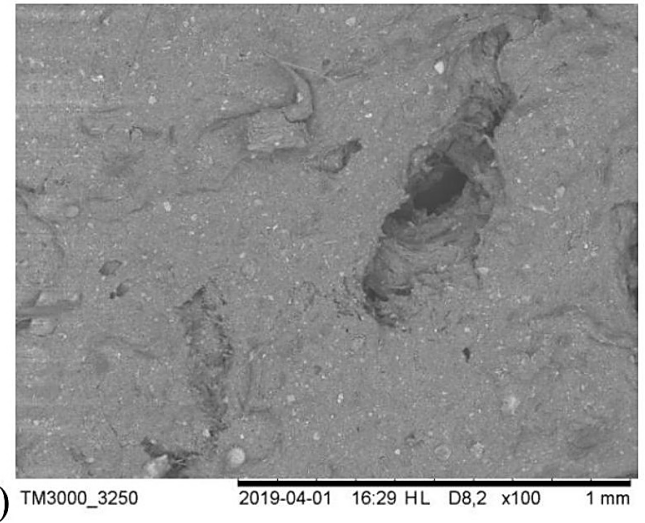

b)
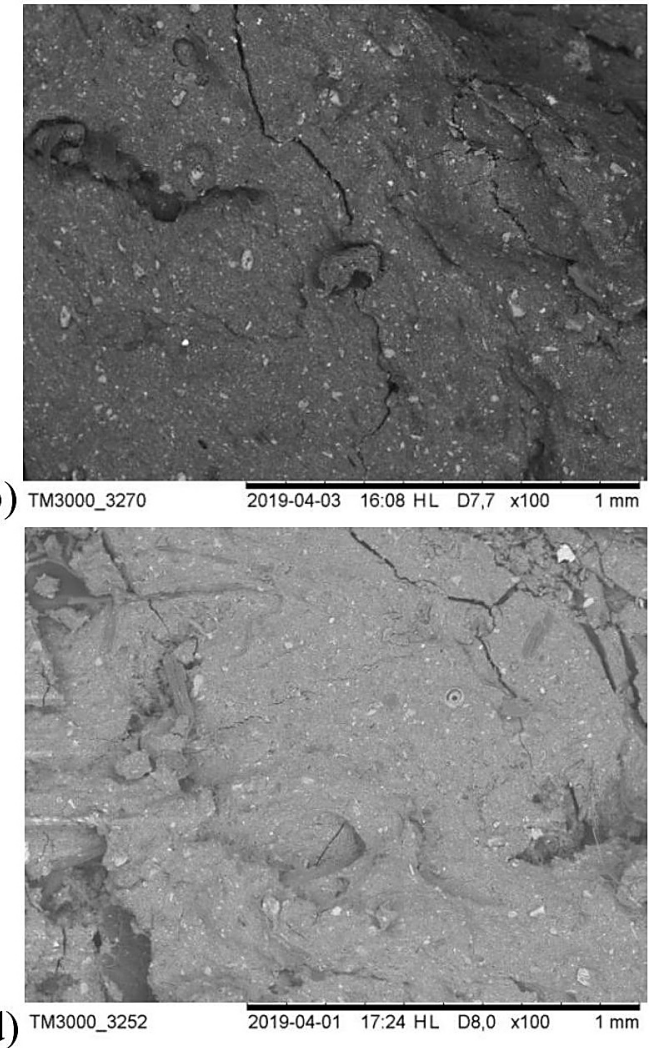

Figure 2. Image of microstructure of dehydrated sewage sludge from "Pomorzany" $[\mathrm{a}, \mathrm{b}]$ and "Zdroje" [c,d] wastewater treatment plants, 100x magnification

a) TM3000_3249
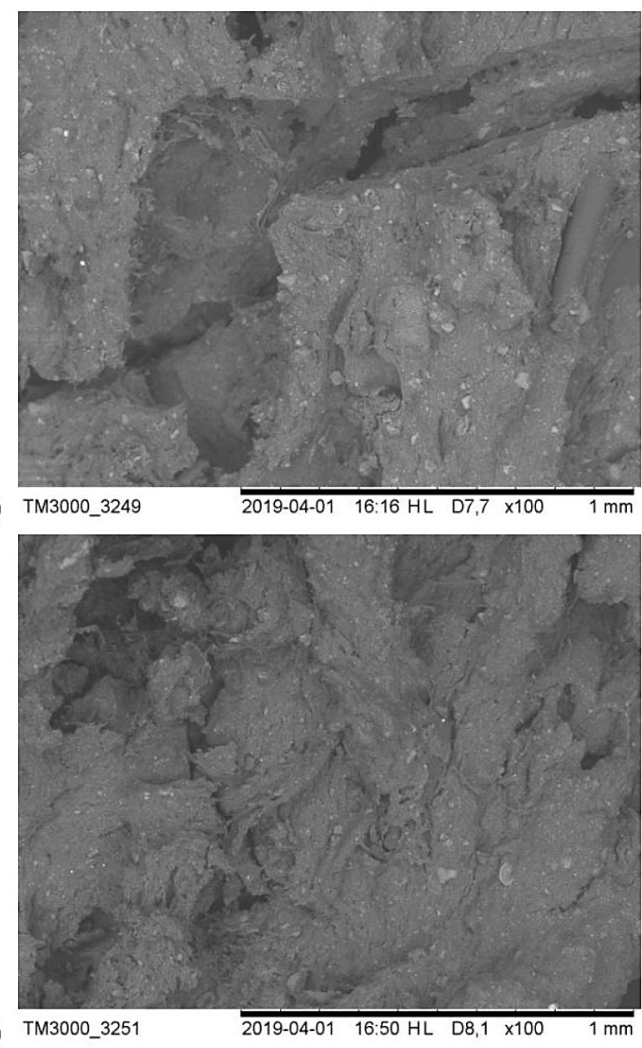

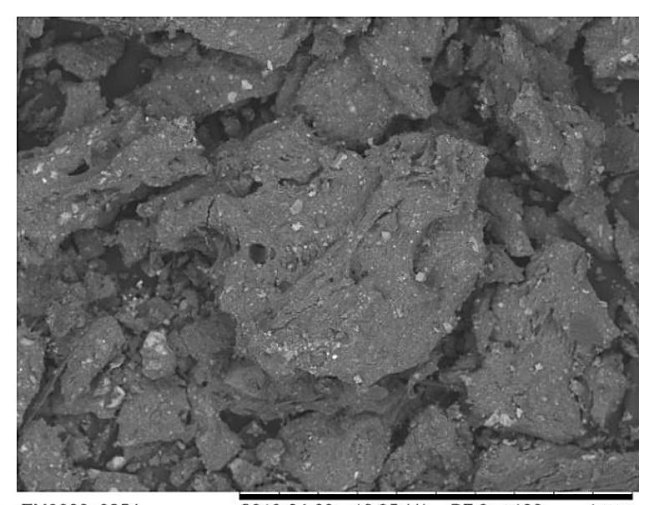

b)

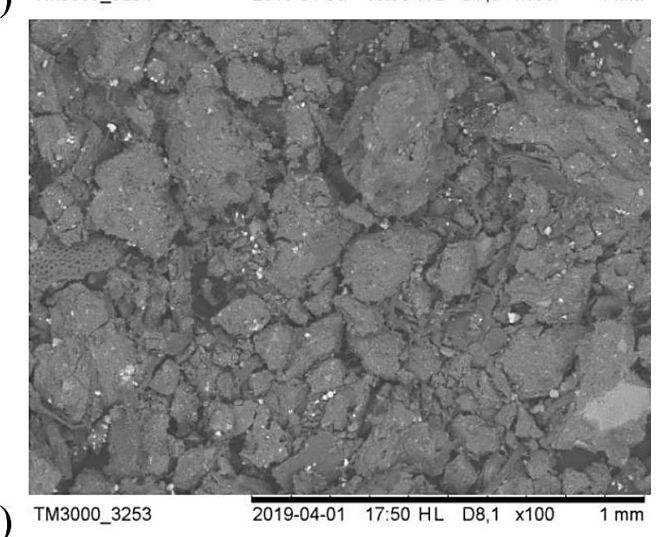

Figure 3. Image of microstructure of dried sewage sludge from "Pomorzany" [a,b] and "Zdroje" [c,d] wastewater treatment plants, 100x magnification 


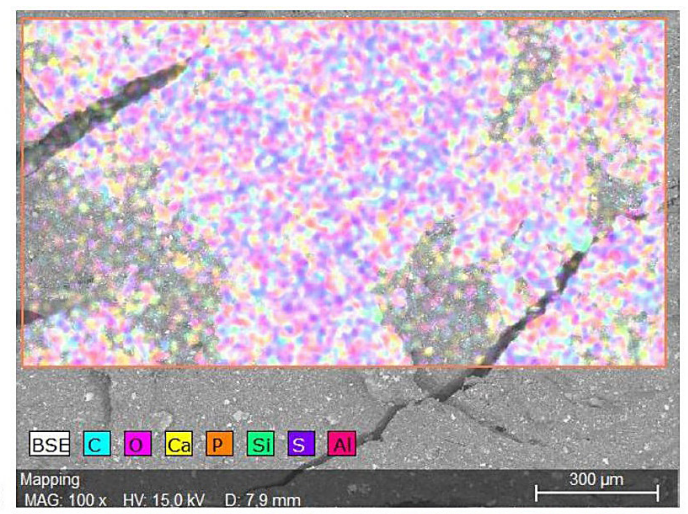

a)

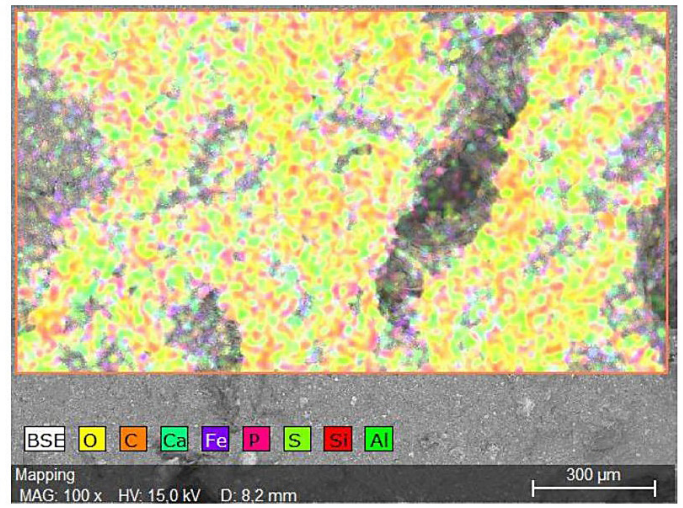

b)

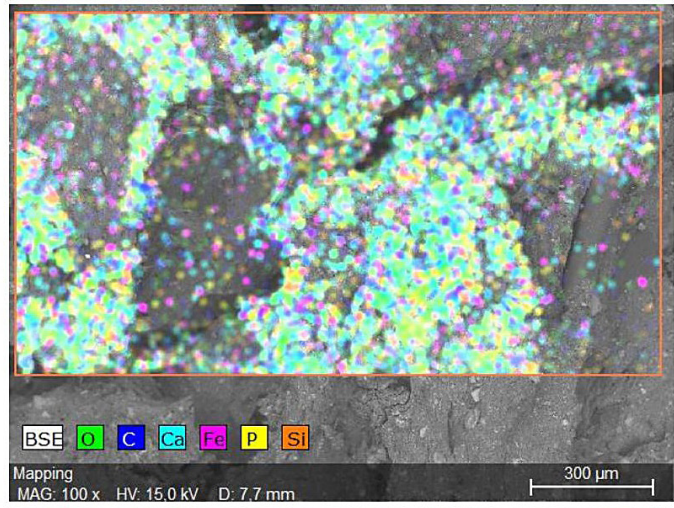

d)

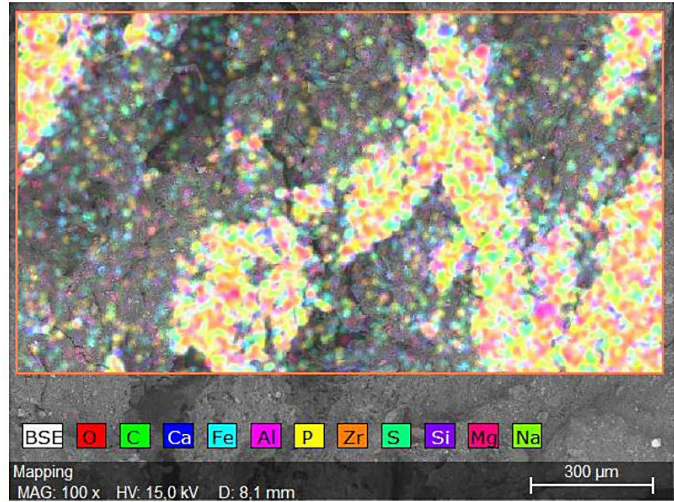

Figure 4. Map of the elements identified on the sewage sludge surface (a) dehydrated and (b) dried sewage sludge from "Pomorzany", (c) dehydrated and (d) dried sewage sludge from "Zdroje"

even in small concentrations [Wang et al. 2003, Pueyo et al. 2004]. As indicated by the presented summarizing of elements - figure 3 , table 3 , mass percent (wt.\%) of iron observed on the surface of the analyzed material ranged from 1.95 to $5.58 \%$. Due to its strong, non-toxic reducing properties, iron is used for the reclamation of the environment, as well as the soil contaminated with trace metals. Iron effectively participates in the coprecipitating and sorption of inorganic pollutants [ Ju et al. 2016]. In the Z2' sample, cadmium was determined at $0.29 \%$. It is believed that major anthropogenic sources of $\mathrm{Cd}$ in soils are atmospheric deposition and P-fertilizers. However, the deposition rate of $\mathrm{Cd}$ in the industrialized countries should be further reduced due to the decreased production and strict environmental regulations. The EU regulations and national policies permit the use of compost materials for agricultural purposes when the $\mathrm{Cd}$ content in composts varies between 0.2 and $1.3 \mathrm{mg} \cdot \mathrm{kg}^{-1}$ [Ociepa-Kubicka and Ociepa 2012, Eckel et al. 2008, Beavington et al. 2004]. The concentration of other heavy metals was so low that it cannot be detected by EDS.

Calcium, iron, phosphorus, sulphur and silicon in varying proportions amounted to $85.9 \%$ of the total content of the observed micro and macro elements. Nearly a twice higher percentage of sulfur $(1.94 \%)$ was observed in the municipal sludge from the "Zdroje" WWTP in comparison with the sludge from "Pomorzany" $(1.00 \%)$. The sulfur present in the sewage sludge for thermal disposal, affects the occurrence of an unfavorable corrosion of structural elements of boilers. Additionally, it contributes to the formation of organic and inorganic contaminants [Skawińska and Kuklis 2014]. The materials from both treatment plants are characterized by a similar occurrence of phosphorus $-2.88 \%$ and $2.32 \%$ on average, respectively. The phosphorus present in sewage sludge is a valuable element that can be recovered as well as used directly for fertilizing or reclamation purposes. However, due to heavy metal contamination, sewage sludge management is subject to strict regulations (e.g. Regulation (EC) No. 2003/2003 of the European Parliament and Council of 13th October 2003) [Cieślik et al. 2015]. The studies carried out by the authors in previous years indicate the content of phosphorus in municipal sewage sludge is from 12.3 to 48.1 $\mathrm{g} \cdot \mathrm{kg}-1$ d.m. [Iżewska et al. 2007, Kiper 2017]. According to Parés Viader, the concentration of phosphorus in the sewage sludge ash depends on the combustion technology and might occur in 
Table 3. Percentage share of elements identified on the sewage sludge surface

\begin{tabular}{|c|c|c|c|c|c|c|c|c|c|c|c|c|}
\hline & \multicolumn{5}{|c|}{ WWTP Pomorzany } & \multicolumn{5}{|c|}{ WWTP Zdroje } & \multicolumn{2}{|c|}{ Total } \\
\hline & \multicolumn{2}{|c|}{$\begin{array}{c}\text { dried on a } \\
\text { moisture analyzer }\end{array}$} & \multicolumn{2}{|c|}{$\begin{array}{l}\text { dried sewage } \\
\text { sludge dryer }\end{array}$} & \multirow{2}{*}{ mean } & \multicolumn{2}{|c|}{$\begin{array}{c}\text { dried on a } \\
\text { moisture analyzer }\end{array}$} & \multicolumn{2}{|c|}{$\begin{array}{l}\text { dried sewage } \\
\text { sludge dryer }\end{array}$} & \multirow{2}{*}{ mean } & \multirow{2}{*}{ mean } & \multirow{2}{*}{$\begin{array}{l}\text { standard } \\
\text { deviation }\end{array}$} \\
\hline & P1' & P2' & P1" & P2" & & Z1' & $Z^{\prime} 2^{\prime}$ & Z1" & Z2" & & & \\
\hline $\mathrm{Ca}$ & 3.59 & 2.81 & 4.58 & 3.35 & 3.58 & 5.31 & 4.79 & 4.20 & 4.93 & 4.81 & 4.19 & 0.87 \\
\hline $\mathrm{Fe}$ & 2.80 & 1.94 & 2.79 & 2.20 & 2.43 & 5.59 & 5.68 & 2.35 & 4.37 & 4.50 & 3.46 & 1.53 \\
\hline $\mathrm{Si}$ & 2.39 & 1.89 & 1.67 & 2.56 & 2.13 & 1.49 & 1.17 & 1.53 & 1.37 & 1.39 & 1.76 & 0.49 \\
\hline $\mathrm{P}$ & 2.29 & 1.82 & 2.97 & 2.23 & 2.32 & 3.44 & 3.06 & 2.83 & 2.20 & 2.88 & 2.60 & 0.55 \\
\hline$S$ & 1.08 & 1.11 & n.d. ${ }^{*}$ & 0.82 & 1.00 & 1.85 & 1.51 & 1.61 & 2.80 & 1.94 & 1.54 & 0.66 \\
\hline $\mathrm{Al}$ & 0.86 & 0.78 & 0.59 & 0.70 & 0.73 & 0.99 & 0.84 & 1.80 & 1.03 & 1.16 & 0.95 & 0.37 \\
\hline $\mathrm{Mg}$ & 0.61 & 0.60 & 0.62 & 0.50 & 0.58 & 0.51 & 0.58 & 0.55 & 0.49 & 0.53 & 0.56 & 0.05 \\
\hline $\mathrm{Ti}$ & 0.21 & n.d. ${ }^{*}$ & n.d. ${ }^{*}$ & n.d. ${ }^{*}$ & 0.21 & n.d. ${ }^{*}$ & n.d. ${ }^{*}$ & n.d. ${ }^{*}$ & n.d. ${ }^{*}$ & n.d. ${ }^{*}$ & 0.21 & - \\
\hline $\mathrm{K}$ & n.d. ${ }^{*}$ & n.d. ${ }^{*}$ & n.d. ${ }^{*}$ & 0.22 & 0.22 & n.d. ${ }^{*}$ & n.d. ${ }^{*}$ & n.d. ${ }^{*}$ & n.d. ${ }^{*}$ & n.d. ${ }^{*}$ & 0.22 & - \\
\hline $\mathrm{Cd}$ & n.d. ${ }^{*}$ & n.d. ${ }^{*}$ & n.d. ${ }^{*}$ & n.d. ${ }^{*}$ & n.d.* & n.d. ${ }^{*}$ & 0.29 & n.d. * & n.d. ${ }^{*}$ & 0.29 & 0.29 & - \\
\hline
\end{tabular}

*not detected

the range of $88.4 \pm 21-96.0 \pm 15 \mathrm{~g} \cdot \mathrm{kg}^{-1}$ d.m. [Parés Viader et al. 2017].

The average content of magnesium did not vary considerably and amounted to $0.56 \%$. The remaining elements observed on the surface of some of the materials studied included titanium $(0.21 \%-\mathrm{P} 1$ ' sample) and potassium $(0.22 \%-\mathrm{P} 2 "$ sample).

\section{CONCLUSIONS}

- The analyzed sewage sludges were characterized by slightly alkaline $\mathrm{pH}$ in the range of 7.90-8.42 and a high content of organic matter in the range of 68.50 to $69.43 \%$.

- Iron, calcium and phosphorus were the most abundant elements observed on the surface of dried and dehydrated sewage sludge.

- The percentage of phosphorus observed on the surface of analyzed materials was from 1.82 to $3.44 \%$; due to the presence of this element, the sewage sludge can be used as an organic fertilizer product or alternative source of phosphorus.

- The sewage sludge from the "Zdroje" WWTP contained higher concentrations of sulfur, whereas a greater amount of silicon was determined in the material from "Pomorzany" WWTP,

- The structure of the dehydrated sludge was mainly macroporous,

- Among potentially toxic heavy metals, cadmium was detected in the sample from Zdroje" WWTP.

\section{REFERENCES}

1. Beavington F, Cawse PA, Wakenshaw A (2004) Comparative studies of atmospheric trace elements: improvements in air quality near a copper smelter. Science of Total Environment 332, 39-49, DOI: 10.1016/j.scitotenv.2004.04.016.

2. Cieślik, B. M., Namieśnik, J., \& Konieczka, P. (2015). Review of sewage sludge management: standards, regulations and analytical methods. Journal of Cleaner Production, 90, 1-15. DOI: 10.1016/j.jclepro.2014.11.031.

3. Cornel, P., Meda, A. \& Bieker, S. (2011) Wastewater as a source of energy, nutrients, and service water. Treatise on Water Science (P. Wilderer, ed.). Elsevier, Oxford, 337-375.

4. European Statistical Office Eurostat (2019) (https:// ec.europa.eu/eurostat/ (07.05.2019)).

5. Eckel, H., Roth, U., Döhler, H., \& Schultheis, U. (2008). Assessment and reduction of heavy metal input into agro-ecosystems. Trace elements in animal production systems, 33-43.

6. Głowacka, A., Rucińska, T., Kiper, J. (2017). The slag original from the process of sewage sludge incineration selected properties characteristic. E3S Web of Conferences 22, 00054-0058. EDP Sciences. DOI: $10.1051 / \mathrm{e} 3$ sconf/20172200054.

7. Henclik, A., Kulczycka, J., Gorazda, K., Wzorek, Z. (2014). Conditions of sewage sludge management in Poland and Germany. Engineering and Protection of Environment, 17, 185-198 (in Polish).

8. Iżewska, A., Krzywy, E., \& Balcer, K. (2007). Impact of sewage sludge and composts prepared from sewage sludge on the content and uptake of macronutrients by straw of miscanthus sacchariflorus. Polish Journal of Chemical Technology, 9(3), $56-59$. 
9. Ju, F., Li, B., Ma, L., Wang, Y., Huang, D., \& Zhang, T. (2016). Antibiotic resistance genes and human bacterial pathogens: co-occurrence, removal, and enrichment in municipal sewage sludge digesters. Water research, 91, 1-10. DOI: 10.1016/j. watres.2015.11.071.

10. Kaplan, D. I., Knox, A. S. (2004). Enhanced contaminant desorption induced by phosphate mineral additions to sediment. Environmental science \& technology, 38(11), 3153-3160, DOI 10.1021/ es035112f.

11. Kelessidis, A.; Stasinakis, A. S. (2012) Comparative study of the methods used for treatment and final disposal of sewage sludge in European countries. Waste management, 32(6), 1186-1195, DOI: 10.1016/j.wasman.2012.01.012.

12. Kiper, J. (2017). The possibilities of natural development of ash-sludge blends. Inżynieria Ekologiczna, 18(3), 74-82. DOI: 10.12912/23920629/70260.

13. Lu, Y., Wu, X., \& Guo, J. (2009). Characteristics of municipal solid waste and sewage sludge co-composting. Waste Management, 29(3), 1152-1157. DOI: 10.1016/j.wasman.2008.06.030.

14. Niesler, J., Nadziakiewicz, J. (2013). Evaluating possibilities for co-combustion of municipal waste and sewage sludge in the Silesian agglomeration. Piece Przemysłowe \& Kotły, (9-10), 29-41 (in Polish).

15. Ociepa-Kubicka A., Ociepa E. (2012) Toxic effects of heavy metals on plants, animals and humans, Engineering and Protection of Environment, 15(12), 169-180.

16. Parés Viader, R., Jensen, P. E., Ottosen, L. M., Thomsen, T. P., Ahrenfeldt, J., \& HauggaardNielsen, H. (2017). Comparison of phosphorus recovery from incineration and gasification sewage sludge ash. Water Science and Technology, 75(5), 1251-1260. DOI: 10.2166/wst.2016.620.

17. Pueyo, M., Lopez-Sanchez, J. F., Rauret, G. (2004). Assessment of $\mathrm{CaCl} 2, \mathrm{NaNO} 3$ and NH4NO3 extraction procedures for the study of $\mathrm{Cd}, \mathrm{Cu}, \mathrm{Pb}$ and $\mathrm{Zn}$ extractability in contaminated soils. Analytica chimica acta, 504 (2), 217-226. DOI: 10.1016/j. aca.2003.10.047.
18. Resolution No. 88 of the Council of Ministers of 1 July 2016 on the National Waste Management Plan 2022; (Monitor Polski No. 88, item 784).

19. Rio, S., Faur-Brasquet, C., Le Coq, L., Le Cloirec, P. (2005). Structure characterization and adsorption properties of pyrolyzed sewage sludge. Environmental science \& technology, 39(11), 4249-4257. DOI: $10.1021 / \mathrm{es} 0497532$.

20. Schröder, P., Navarro-Aviñó, J., Azaizeh, H., Goldhirsh, A. G., DiGregorio, S., Komives, T., Ranalli, A. (2007). Using phytoremediation technologies to upgrade waste water treatment in Europe. Environmental Science and Pollution Research-International, 14(7), 490-497.

21. Singh, R. P., Agrawal, M. (2008). Potential benefits and risks of land application of sewage sludge. Waste management, 28(2), 347-358. DOI: 10.1016/j.wasman.2006.12.010.

22. Skawińska, A., Kuklis, I. (2014). Evaluation of energy usefulness of the municipal sewage sludge based on the analysis of physico-chemical parameters. Przegląd Górniczy, 70(12), 74-77.

23. The Ministry of the Environment (2018). Strategy of proceeding with municipal sewage sludge for the years 2019-2022. (https:/www. gov.pl/documents/1379842/1381036/Strategia_postępowania_z_komunalnymi_osadami_ ściekowymi na lata 2019-2022.pdf/7ce1630d5dec-e0ef-2083-074e06dc2d16 (07.05.2019)) (in Polish).

24. Wang, Q. R., Cui, Y. S., Liu, X. M., Dong, Y. T., Christie, P. (2003). Soil contamination and plant uptake of heavy metals at polluted sites in China. Journal of Environmental Science and Health, Part A, 38(5), 823-838. DOI: 10.1081/ESE120018594.

25.Zorpas, A. A., Coumi, C., Drtil, M., \& Voukalli, I. (2011). Municipal sewage sludge characteristics and waste water treatment plant effectiveness under warm climate conditions. Desalination and Water Treatment, 36(1-3), 319-333. DOI: 10.5004/ dwt.2011.2773. 